\title{
TIME TO LOOK AGAIN? COPYRIGHT AND FREEDOM OF PANORAMA
}

\author{
Jonathan Barrett*
}

Copyright grants exclusive rights to authors of qualifying works. However, the Copyright Act 1994 permits reproduction, communication and commercial exploitation of certain artistic works which are on permanent public display. This exclusion from copyright, which is widely referred to as "freedom of panorama", is distinguishable from other permitted uses which tend to be narrow in scope and commonly manifest an element of fair dealing. Like other corresponding provisions of British heritage copyright legislation, New Zealand's freedom of panorama exclusion is significantly wider than comparable permitted uses in other jurisdictions.

This article examines freedom of panorama in New Zealand. Note is taken of the Waitangi Tribunal report Wai 262, which considered among other issues the protection of Māori cultural treasures within the intellectual property law system. As points of comparison, selected overseas approaches to freedom of panorama are outlined. This article questions whether the current exclusion strikes an appropriate balance between competing rights and interests.

\section{INTRODUCTION}

"The main function of copyright law is to strike a fair balance between the rights of the copyright holder and the users of protected works". ${ }^{1}$ And so, while copyright holders enjoy exclusive exploitation rights over their qualifying works, ${ }^{2}$ pt 3 of the Copyright Act 1994 provides for ad hoc and independent permitted uses of copyright works. These exclusions tend to be specific and narrow in scope, and commonly manifest an element of fair dealing. "Fair dealing" is not statutorily defined, but "[i]t is generally recognised that for fair dealing to be fair it should not compete with the author's

* Senior Lecturer, School of Accounting and Commercial Law, Victoria University of Wellington. I am grateful to the anonymous reviewer whose comments greatly improved this article. Any errors are mine alone.

1 Law Reform Division Reform of the Copyright Act 1962: A discussion paper (Department of Justice, 1985) at [1.1].

2 See Copyright Act 1994, s 16. Qualifying works are identified in s 14(1). 
work - for example, by diminishing his or her sales."3 Section 73 of the Copyright Act 1994 establishes what is widely referred to as "freedom of panorama". ${ }^{4}$ In terms of this exclusion, one may reproduce in two dimensions certain three-dimensional artistic works (buildings, sculptures, models for buildings, or works of artistic craftsmanship "that are permanently situated in a public place or in premises open to the public"). ${ }^{5}$ Such reproductions may be issued to the public, ${ }^{6}$ and the artist has no right to compensation for any lost capacity to exploit their work. ${ }^{7}$ As Susy Frankel observes, "if the statutory criteria are established there is a right to use the material even if that use would not be considered to be fair dealing". ${ }^{8}$

Radford $v$ Hallenstein Bros Ltd, New Zealand's principal freedom of panorama case, demonstrates how this permitted use can work in practice. ${ }^{9}$ Auckland City Council commissioned John Radford, a prominent New Zealand artist, to create the sculpture TIP for Western Park on Ponsonby Road. TIP has become an iconic landmark for the city. When the fashion retailer Hallensteins reproduced an

3 Law Reform Division, above n 1, at [4.2]. In copyright terminology, the term "author" refers to anyone who creates copyright-protected works.

4 While "freedom of panorama" is commonly encountered in contemporary commentaries, its use is recent. It is then a convenient anachronism to refer to older exclusions as freedom of panorama. The term appears to be derived from the German Panoramafreiheit. See below n 22 on the origins of this word.

5 Copyright Act 1994, s 73(1). Section 73 was amended by the Copyright (New Technologies) Amendment Act 2008. The amendments were not significant and were not discussed in the memorandum to the Bill. The permitted ways of reproducing the affected works in two dimensions are "copying the work by making a graphic work representing it", "copying the work by making a photograph or film of it" or "communicating to the public a visual image of the work": see Copyright Act 1994, s 73(2). It is assumed that a photograph of an affected work is a copy of that work. For a discussion of the copyright status of photographs of public sculptures, see Alifia Qonita Sudharto "Copyright Law and the Freedom of Panorama: the Right to Commercial Photographs of Protected Works" (LLM Dissertation, Victoria University of Wellington, 2014) at 51.

6 See Copyright Act 1994, s 73(3).

7 Moral rights, which protect authors' non-economic interests in their works (see Copyright Act 1994, pt 4), are not generally affected by freedom of panorama.

8 Susy Frankel Intellectual Property in New Zealand (2nd ed, LexisNexis, Wellington, 2011) at [6.7.11(a)].

9 The judicial record of the dispute comprises three reported decisions: Radford v Hallensteins Bros Ltd DC Auckland CIV 2005-004-3008, 17 July 2006 [Radford (2006)], heard by Judge Hubble in the District Court, which related to claims of breach of copyright and the moral right of integrity; Radford v Hallenstein Bros Ltd HC Auckland CIV-2006-404-4881, 22 February 2007 [Radford (2007)], heard by Keane J in the High Court, was the appeal from the District Court; and Radford v Hallensteins Bros Ltd [2009] DCR 907 [Radford (2009)], heard by Judge Joyce, concerned an application by Hallensteins to strike out Radford's moral rights claim. The registered name of the company is "Hallenstein Bros Ltd" but the firm is more commonly known as "Hallensteins". 
image of the sculpture on T-shirts, Radford objected, partly on the grounds that his opportunities to exploit the work would be reduced. ${ }^{10}$ In the District Court, Judge Hubble observed: ${ }^{11}$

... if an artist creates a sculpture or building which is permanently in public, their one opportunity of obtaining a reward is for creating the work in the first place. Thereafter, there is no support for the view that such works, permanently in a public place, cannot be commercial[1y] exploited in a two-dimensional form.

A permitted use may not have to be fair but the Radford decision prompts the question whether $\mathrm{s}$ 73, which allows apparently unfair outcomes, strikes the appropriate balance between copyright and use. Most artists in New Zealand struggle to make a living from their artistic practice. ${ }^{12}$ A provision permitting highly profitable commercial users to appropriate others' artistic works deserves reconsideration. ${ }^{13}$

The Berne Convention, ${ }^{14}$ which establishes minimum copyright standards among its signatories, implicitly permits, but does not mandate, freedom of panorama. ${ }^{15}$ In the European Union, freedom of panorama is one of the listed exclusions to copyright contemplated by the InfoSoc Directive. ${ }^{16}$ InfoSoc has an overall harmonisation purpose, including harmonising compliance with the Berne Convention, but Union members remain free to decide the extent of their copyright exclusions. Consequently, across the European Union, freedom of panorama provisions vary considerably. ${ }^{17}$ The

10 For an interview with Radford about the case, see Kim Knight "Surreal Estate" Sunday Star Times (online ed, New Zealand, 19 June 2011). For an in-depth analysis of the case, see Adelaide Dunne "The Moral Right of Integrity for Visual Artists in New Zealand Problems in Practice and in Theory" (LLB (Hons) Dissertation, University of Auckland, 2015) at 25-39.

11 Radford (2006), above n 9, at [33]. It seems likely that Hallensteins would not have been permitted to sell, say, cuff links that replicated the sculptures in three dimensions.

12 For the fiscal year ending 31 March 1999, New Zealand visual artists' median income from their principal artistic occupation was $\$ 4,000$ (26 per cent of their total income). At that time, the median income of all New Zealanders in paid employment was $\$ 27,934$. See Creative NZ "Portrait of the Artist: A Survey of Practising Professional Artists in New Zealand" (2003) <www.creativenz.govt.nz>.

13 See for example Catherine Harris "Hallenstein profit jumps nearly 40pc, sales rebound" (27 March 2015) Stuff <www.stuff.co.nz>.

14 Berne Convention for the Protection of Literary and Artistic Works 828 UNTS 221 (adopted 9 September 1886, revised on 24 July 1971 and amended 28 September 1979) [Berne Convention]. The text of the Convention has been revised on several occasions, including at Rome on 2 June 1928, at Stockholm on 14 July 1967 and at Paris on 24 July 1971

15 Article 9(2).

16 Directive 2001/29/EC on the Harmonisation of Certain Aspects of Copyright and Related Rights in the Information Society [2001] OJ L167/10, art 5.3(h) [InfoSoc Directive].

17 The apparently ephemeral popularity of the Pokémon GO game, which requires players to capture images of public buildings and public artworks, highlights the arbitrary nature of freedom of panorama in different 
United Kingdom's version is substantially the same as New Zealand's freedom of panorama, whereas the Swedish Supreme Court and the French legislature have taken far more restrictive approaches. A Berne-compliant jurisdiction, such as New Zealand, therefore has significant leeway in crafting exclusions which strike a balance, appropriate for local circumstances, between the rights of copyright holders and users of protected works.

The Waitangi Tribunal report Wai 262 comprehensively analysed Māori expectations about kaitiakitanga (guardianship) of their taonga (cultural treasures) and intellectual property rights. ${ }^{18}$ Whakairo (carving) is an exceptional feature of Māori artistic practice, ${ }^{19}$ and, as the report noted, freedom of panorama "applies to some whare whakairo and other publicly displayed copyrighted taonga works". ${ }^{20}$ The report recognised that "[t]he Treaty interest must of course be balanced with other interests", but also noted that "it is high time to elevate the Treaty interest to its rightful place alongside them". ${ }^{21}$ In considering the interests of copyright holders and users in the area of freedom of panorama, this proposed recalibration of balance deserves particular attention.

This article examines freedom of panorama and, taking particular account of Wai 262, inquires whether this permitted use strikes an appropriate balance between copyright owners' and users' interests in the specific New Zealand context. The article is structured as follows. After this introduction, Part II provides an overview of freedom of panorama and identifies the principal interpretative issues that arise from the exclusion. Part III considers the relevant exclusions to copyright under the Berne Convention, and also looks at how certain European Union members comply with the InfoSoc Directive. The ways in which different European jurisdictions have responded to the Berne Convention and InfoSoc indicate alternatives to British heritage copyright for New Zealand. Part IV considers whether New Zealand has achieved the appropriate balance of interests in relation to freedom of panorama. Part $\mathrm{V}$ draws conclusions and makes policy recommendations.

jurisdictions: see Emma Perot "Gotta catch 'em all without infringing copyright: Pokémon and Freedom of Panorama" (30 July 2016) The IPKat <www.ipkitten.blogspot.co.nz>.

18 See Waitangi Tribunal Ko Aotearoa Tēnei: A Report into Claims Concerning New Zealand Law and Policy Affecting Māori Culture and Identity Te Taumata Tuatahi (Wai 262, 2011) [Wai 262].

19 In his canonical history of world art, Ernst Gombrich included only one image from Australasia and Oceania, that of a Māori chief's carved lintel: see EH Gombrich The Story of Art (Pocket ed, Phaidon, London, 2006) at plate 22 .

20 Wai 262 , above n 18 , at 35

21 At 700 


\section{FREEDOM OF PANORAMA}

Panoramafreiheit (also known as Straßenbildfreiheit) originated in the German states preunification. ${ }^{22}$ Mélanie Dulong de Rosnay and Pierre-Carl Langlais report that "in 1840, the Kingdom of Bavaria edicted the very first 'freedom of panorama': an exception to this general rule regarding the 'work of arts and architecture in their exterior contours' situated in a public space". ${ }^{23}$ The exclusion was included in the country's first national copyright legislation. ${ }^{24}$ Freedom of panorama has been received most favourably in North European countries and has been included in British heritage copyright legislation for more than a century. ${ }^{25}$

\section{A Development}

The Copyright Act 1911 (UK) "was in substance, though not in form, Imperial legislation". ${ }^{26}$ Consequently, as Geoff McLay observes of the Copyright Act 1913, New Zealand's first comprehensive copyright legislation, ${ }^{27}$ "[a]ll effort was made in 1913 to essentially replicate the Imperial Act as a domestic New Zealand statute." 28 Under the 1913 Act, which replicated verbatim the corresponding provision of the 1911 Act ${ }^{29}$ the following did not constitute infringement: ${ }^{30}$

The making or publishing of paintings, drawings, engravings, or photographs of a work of sculpture or artistic craftsmanship, if permanently situate in a public place or building, or the making or publishing of paintings, drawings, engravings, or photographs ... not in the nature of architectural drawings ...

Since there is no explanation of this exclusion in the 1911 Bill, the debates preliminary to the 1911 Act might prove illuminating. However, in her analysis of the parliamentary discussion, Isabella

22 Mélanie Dulong de Rosnay and Pierre-Carl Langlais note "even in Germany there was no acknowledged and uniform name to designate this array of exceptions and restrictions. While the concept was 170-years old, the word only emerged in the 1990s. 'Panoramafreiheit' was likely of Swiss origin". See Mélanie Dulong de Rosnay and Pierre-Carl Langlais "Public artworks and the freedom of panorama controversy: a case of Wikimedia influence" (2017) Internet Policy Review <www.policyreview.info>.

23 Dulong de Rosnay and Langlais, above $\mathrm{n} 22$.

24 Kunstschutzgesetz 1876, §6

25 See Copyright Act 1911 (UK) 1 \& 2 Geo V, c 46, s 2(1)(iii).

26 Report of the Copyright Committee [1959] AJHR H46 [Dalglish Report] at 6.

27 New Zealand's first copyright legislation governed reproduction of books only: see Copyright Ordinance 1842 5 Vict 18.

28 Geoff McLay "New Zealand and the Imperial copyright tradition" in Uma Suthersanen and Ysolde Gendreau (eds) A Shifting Empire: 100 Years of the Copyright Act 1911 (Edward Elgar Publishing, Cheltenham, 2013) 30 at 31 .

29 See Copyright Act 1911 (UK), above n 25, para (iii) of the proviso to s 2(1).

30 Copyright Act 1913, para (c) of the proviso to s 5(1). 
Alexander throws little light on why the exclusion was included. She reports that in response to a question in the House of Lords about the potential detriment of the exclusion to artists: ${ }^{31}$

Viscount Haldane, who had charge of the Bill in the Lords, responded by pointing out that the Bill actually improved the position of artists, because under the current law anyone could make a sketch of a statue, while the Bill limited this to public places - a limitation he claimed to be in the 'public interest'.

Beyond Viscount Haldane's somewhat gnomic statement, there is very little information to explain the policy underpinnings of freedom of panorama in British heritage copyright law.

The Copyright Act 1962, which replaced the 1913 Act, was "largely based on" the Copyright Act 1956 (UK) and the Dalglish Report. ${ }^{32}$ The Dalglish Report in turn followed the recommendations of the Gregory Committee, which preceded the Copyright Act 1956 (UK), on fair dealing, but did not consider s 9(3) of the 1956 Act on freedom of panorama. ${ }^{33}$ As Andrew Brown observes, "the Copyright Act 1962 contained few if any provisions which actually recognised that New Zealand might have interests substantially different from those of copyright exporting countries". ${ }^{34}$ Partly reflecting developments in technology, the freedom of panorama provisions of the 1962 Act were more extensive than the 1913 Act, with subss (4) and (5) of s 20 respectively establishing exclusions for works of architecture and "a sculpture, or in a work of artistic craftsmanship (not being a work of architecture and not being a painting, drawing, engraving, or photograph), or in a mural". ${ }^{35}$ Copyright in these works was: ${ }^{36}$

... not infringed by the making of a painting, drawing, engraving, or photograph of the work or the inclusion of the work in a cinematograph film or television broadcast if the work is permanently situated in or in view of a public place ... or in any premises open to the public.

This provision was notable for its inclusion of murals in scope of freedom of panorama, unlike s 20(3) of the 1956 Act. No explanation of s 20 was given; the Bill merely stated "copyright in artistic works is not infringed by specified types of fair dealing with those works". ${ }^{37}$ Indeed, pt III of the 1962 Act included freedom of panorama under the title of fair dealing.

31 Isabella Alexander Copyright Law and the Public Interest in the Nineteenth Century (Hart Publishing, Oxford, 2010) at 285 .

32 Copyright Bill 1962 (63-1) (explanatory note).

33 Dalglish Report, above n 26, at 146.

34 Law Commission Intellectual Property: The Context for Reform (NZLC R13, 1990) at 41.

35 See Andrew Brown and Anthony Grant The Law of Intellectual Property in New Zealand (Butterworths, Wellington, 1989) at [4.161].

36 Copyright Act 1962, s 20(5).

37 See the Copyright Bill 1962 (63-1) (explanatory note) (emphasis added). 
The Department of Justice reports precursory to the Copyright Act 1994 gave no consideration to freedom of panorama. The two principal reasons for the new Act were compliance with TRIPS ${ }^{38}$ and accommodating new technology. ${ }^{39}$ No explanation was given for the provision that became s $73 .{ }^{40}$ The freedom of panorama provision under the current 1994 Act has a narrower scope than its immediate predecessor since it does not include murals, and applies to affected works "that are permanently situated in a public place or in premises open to the public". ${ }^{41}$ In light of the contemporary popularity of street art, ${ }^{42}$ commissioned or otherwise, murals falling outside freedom of panorama is a significant distinction.

The Whitford Committee, ${ }^{43}$ which preceded the introduction of the Copyright, Patents and Designs Act 1988 (UK), did consider freedom of panorama under s 9(3) of the 1956 Act. The Committee reported: ${ }^{44}$

All but two of us feel that the exceptions now provided by Subsections 3 to 6 should be retained ... The arguments in favour of retention are that the removal of specific exceptions such as these would create uncertainty and also that their deletion might be taken, by some, as meaning that these particular exceptions had been removed. In the case of Subsection 3 we all consider that the expression 'premises open to the public' should be deleted as being of uncertain meaning (if the Subsection is retained).

The Committee did not, then, consider the substance of s 9(3) or its policy underpinnings. It is notable, however, that when contemplating s 9(8), which permitted certain three-dimensional reproductions of two-dimensional artistic works, the Committee observed as a point of general principle that "we see little reason why reproduction in any dimension should not be prohibited, provided there is a sufficient degree of similarity". ${ }^{45}$

38 Agreement on Trade-Related Aspects of Intellectual Property Rights (TRIPS) Annex 1C of the Marrakesh Agreement Establishing the World Trade Organization 1869 UNTS 299 (concluded 15 April 1994, entered into force 1 January 1995).

39 See McLay, above n 28, at 30-31.

40 Copyright Bill 1994 (32-1) (explanatory note)

41 Copyright Act 1994, s 73.

42 Not all street art is two-dimensional: see generally Rafael Schachter The World Atlas of Street Art and Graffiti (Aurum, London, 2013).

43 Copyright and Designs Law: Report of the Committee to consider the Law on Copyright and Designs (Cmnd 6732, March 1977) [Whitford Report].

44 At [685].

45 At [686]. 


\section{B Interpretative Issues}

The term "artistic work" relates to "(i) a graphic work, photograph, sculpture, collage, or model; or (ii) a work of architecture, being a building or a model for a building; or (iii) a work of artistic craftsmanship". ${ }^{46}$ Since s 73 does not permit copying of all artistic works permanently in the public view, affected works must be distinguished from those which attract normal protections. This exercise is not always straightforward. Interpretative difficulties may arise in identifying sculptures and works of artistic craftsmanship, and determining whether an object is permanently or temporarily in a public place.

\section{Sculpture}

The meaning of "sculpture", which is only partially defined in copyright legislation, ${ }^{47}$ was considered by the Court of Appeal in Wham-O MFG Co v Lincoln Industries. ${ }^{48}$ Relying on dictionary definitions and an entry in the Encyclopaedia Britannica, the Court held:49

... where a model which is a sculpture has been created and a cast or mould is later made from that model for the purposes of reproducing the model in metal and plastic or some other form then the articles so produced may be classified as sculptures ... it appears to us to be straining the meaning of the word

"sculpture" to apply it to the discs produced by the injection moulding process.

Since the court in Wham-O did not provide an exhaustive definition, the ordinary meaning of "sculpture" can otherwise be used. ${ }^{50}$ The Oxford English Dictionary defines "sculpture" as the "branch of fine art which is concerned with the production of figures in the round or in relief, either by carving, by fashioning some plastic substance, or by making a mould for casting in metal". ${ }^{51} \mathrm{~A}$ sculpted artefact is the product of these activities. The quality of three dimensions is an essential feature of a sculpture, but not all three-dimensional artworks are sculptures. For example, painted rocks, holograms or collages should not be considered sculptures, whereas cairns or bricolages might be. Despite the ordinary understanding of sculpture as a branch of fine arts, aesthetic appeal or creation

46 Copyright Act 1994, s 2(1)

47 The Copyright Act 1962, s 2(1) provided: "'Sculpture' includes any cast or model made for purposes of sculpture"; the Copyright Act 1994, s 2(1) provides "sculpture includes a cast or model made for purposes of sculpture".

48 Wham-O MFG Co v Lincoln Industries [1984] 1 NZLR 641 (CA).

49 At 662 .

50 See Kevin Garnett, Gillian Davies and Gwilym Harbottle Copinger and Skone James on Copyright (15th ed, Sweet \& Maxwell, London, 2005) at [3-58].

51 Oxford English Dictionary "sculpture, n." <www.oed.org>. 
by an artist is not a requirement for a sculpture under New Zealand copyright law. ${ }^{52}$ Following this mundane approach, three-dimensional commercial signs on public display might be considered sculptures for the purposes of freedom of panorama, although they may otherwise be protected as trademarks.

After the Wham-O decision, "model" was added to the definition of "artistic work" by s 2 of the Copyright Amendment Act 1985. ${ }^{53}$ Consequently, the types of models under consideration in Wham$O$ "would be categorised under 'model' in the definition of 'graphic work', as well as potentially sculptures". ${ }^{54}$ Thus, as a model, an object would not be subject to freedom of panorama but, as a sculpture, it could be. Furthermore, in Thornton Hall Manufacturing Ltd $v$ Shanton Apparel Ltd, ${ }^{55}$ the prototype of an haute couture dress was found to be a "model". Consequently, as Frankel notes: 56

... the distinction between "model" and "sculpture" may be critical. A prototype fashion garment may be classified as a model. If such a garment was displayed in the foyer, say, of a fashion company building, copyright would be infringed if a photograph of the garment were taken. If a model of a building was displayed in the same foyer, taking a photograph of that model would not be an infringement.

\section{Artistic craftsmanship}

Despite works of artistic craftsmanship having "primary relevance to designs", ${ }^{57}$ they may also constitute artistic works which are subject to freedom of panorama. In Bonz Group (Pty) Ltd v Cooke, ${ }^{58}$ which concerned the alleged copying of hand knitted garments, Tipping $\mathrm{J}$ observed that "[t]he composite expression 'artistic craftsmanship' has caused difficulties" ${ }^{59}$ Having considered the disparate views on the meaning of the term expressed by the judges in the leading English case of

52 Compare with Metix (UK) Ltd v GH Maughan (Plastics) Ltd [1997] FSR 718 (Ch) and the requirement of the application of an "artist's hands" in the creation of a sculpture. Garnett, Davies and Harbottle, above n 50, at [3-58] argue that this requirement "ignores the force of the statutory disregard of whether the work has any artistic quality". However, Laddie $\mathrm{J}$ in Metix may have been concerned with how a thing is produced, not what is produced. See also Mann J's respectful disagreement with the Wham-O decision in Lucasfilm Ltd v Ainsworth [2008] EWHC 1878 (Ch), [2009] FSR 103 at [118].

53 Compare Copyright Act 1994, s 2(1) definition of "artistic work".

54 Frankel, above n 8, at [8.3.2(c)] (emphasis added).

55 Thornton Hall Manufacturing Ltd v Shanton Apparel Ltd [1989] 3 NZLR 304 (CA).

56 Frankel, above n 8, at [5.5.4(h)] (footnote omitted).

57 At $[5.5 .4(\mathrm{~g})]$.

58 Bonz Group (Pty) Ltd v Cooke [1994] 3 NZLR 216 (HC).

59 At 222 
George Hensher Ltd v Restawhile Upholstery (Lancs) Ltd, ${ }^{60}$ Tipping J found the Bonz garments to be works of artistic craftsmanship. He reasoned: ${ }^{61}$

They are certainly works of craftsmanship in that those making them, the handknitters, need to impart a sufficient degree

of skill, experience and effort in creating the ultimate product. The idea of craftsmanship relates more to the execution

of the work than to its design. The idea denoted by the word artistic relates more to design than execution.

Following this logic, many commercial objects in publicly accessible places could be considered works of artistic craftsmanship and, therefore, have restricted copyright protection. However, some artistic works may otherwise be protected as designs, if registered under the Designs Act 1953.

\section{Permanent}

The Oxford English Dictionary defines "permanent" as "[c]ontinuing or designed to continue or last indefinitely without change; abiding, enduring, lasting; persistent"; 62 and "temporary" as "[1]asting for a limited time; existing or valid for a time (only); not permanent; transient; made to supply a passing need". ${ }^{63}$ Shelley's Ozymandias ${ }^{64}$ and the fate of the Communist era statues of Marx, Lenin and Stalin indicate the most monumental of sculptures may not, in fact, be permanent. ${ }^{65}$ Certain public artworks are clearly intended to be temporary. For example, when the artists Christo and Jeanne-Claude wrapped the Reichstag in plastic sheeting, the installation was not considered permanent, even though plastic does not degrade for centuries. Because the sculpture was not permanent, vendors of postcards depicting the wrapped building could not benefit from the German freedom of panorama exclusion. ${ }^{66}$ Nevertheless, the sculpted material might be relevant to an

60 George Hensher Ltd v Restawhile Upholstery (Lancs) Ltd [1976] AC 64 (HL).

61 Bonz Group (Pty) Ltd v Cooke, above n 58, at 223.

62 Oxford English Dictionary "permanent, adj. and $n$." <www.oed.com>.

63 Oxford English Dictionary "temporary, adj. and n." <www.oed.com>.

64 "Look on my Works, ye Mighty, and despair!/Nothing beside remains. Round the decay/Of that colossal wreck, boundless and bare/The lone and level sands stretch far away." See Percy Bysshe Shelley "Ozymandias" in Helen Gardner (ed) The New Oxford Book of English Verse 1250 - 1950 (Oxford University Press, Oxford, 1972) 580 at 580.

65 See for example Lavina Stan Transitional Justice in Post-Communist Romania: The Politics of Memory (Cambridge University Press, Cambridge, 2012) at 215.

66 See BBC "Christo wins shrink-wrap rights" (25 January 2002) <http://news.bbc.co.uk>. The Act on Copyright and Related Rights (Urheberrechtsgesetz) 1965 (BGBl I S 1965, p 1273), art 59(1) (World Intellectual Property Organization translation) provides:

It shall be permissible to reproduce, by painting, drawing, photography or cinematography, works which are permanently located on public ways, streets or places and to distribute and publicly communicate such copies. For works of architecture, this provision shall be applicable only to the external appearance. 
assessment of permanence: a statue made of marble will last much longer than one made of cardboard, and cardboard longer than ice, but each of the sculptures may be intended to remain in the public space as long their constituent materials allow. ${ }^{67}$

The distinction between permanent and temporary has particular relevance for tourists. For example, the sculptures displayed on the fourth plinth in London's Trafalgar Square are changed annually. ${ }^{68}$ If these rotating statues are not considered permanent, tourists and postcard vendors may reproduce photographs of the sculptures on three of the plinths but not the fourth. Temporary public sculpture exhibitions, such as those held in Sydney and on Waiheke Island, are becoming increasingly popular. It is implausible to expect visitors to these exhibitions to refrain from photographing the exhibits because they may not be considered permanent. ${ }^{69}$

\section{Are there drafting errors?}

Drafting errors may have been imported into the New Zealand legislation from the United Kingdom, since, "[t]o all intents and purposes the [1962] New Zealand Act was a re-enactment of the 1956 United Kingdom Copyright Act". ${ }^{70}$ Hugh Laddie and his co-authors argue these errors arose from the hasty drafting of the 1956 legislation which was not rectified in the drafting of the Copyright, Patents and Designs Act 1988 (UK). ${ }^{71}$ When a building is photographed and reproduced, its preliminary drawings and plans are also effectively copied, but s 62 of the 1988 Act does not include these underlying works in freedom of panorama. Kevin Garnett and his co-authors observe: ${ }^{72}$

The wording of this section therefore seems to be the result of the draftsman having paraphrased the wording of the 1956 Act which, it seems, was also not wide enough to cover copyright in preliminary drawings and plans. Yet it is clear that Parliament intended the provisions in the 1956 Act to have the same effect as those in the 1911 Act and these latter provisions were not so limited.

67 William Kentridge's monumental reverse graffiti on the walls along the Tiber in Rome was deliberately designed to vanish over an unpredictable number of years: see Julia Friedman "William Kentridge Plans Massive, Vanishing Mural in Rome" (31 August 2015) Hyperallergic <https://hyperallergic.com>.

68 Mark Brown "Trafalgar Square's fourth plinth to show giant thumbs up and horse skeleton" The Guardian (online ed, United Kingdom, 7 February 2014).

69 While its observation specifically related to incidental copying, rather than freedom of panorama, the Dalglish Report, above n 26, at 128 recorded the concerns of the Publicity Division of the Tourist and Publicity Department about tourists' accidental copyright infringement.

70 Law Commission, above n 34, at 41.

71 See Hugh Laddie and others The Modern Law of Copyright and Designs Volume 1 (3rd ed, Butterworths, London, 2000) at [20.76].

72 Garnett, Davis and Harbottle, above n 50, at [9-170] (footnote omitted). 
The wording of s 73 is not identical to s 62 of the United Kingdom Act, and does not include the phrase "in such a work" which commentators find problematic in the United Kingdom provision. ${ }^{73}$ Nevertheless, the necessity for judicial shoring up of s 73 was recognised in Radford, where the principle of efficacy was employed to prevent infringement of underlying works fatally eroding "the immunity s 73 apparently confers". ${ }^{74}$

\section{Freedom of Panorama and Other Laws}

Freedom of panorama may be trumped by cultural heritage laws, ${ }^{75}$ national security laws, ${ }^{76}$ design law, ${ }^{77}$ or trademark registration. In the last regard, the guardians of the iconic Sydney Opera House attracted attention, if not ridicule and opprobrium, for registering photographic images of the building from most conceivable angles as trademarks. ${ }^{78}$ Implying the pettiness of the trademark registration, Bernard Lane reports that an entrepreneur may no longer produce a snow dome or novelty hat reproducing the building. ${ }^{79}$ (Since a snow dome and a hat have three dimensions, they could not have been produced without breaching copyright. ${ }^{80}$ ) In a sober view, the Opera House trustees have acted similarly to Italian governments in restricting how their cultural treasures are portrayed, to control the ways in which images of a New World icon may be commercially reproduced. The trustees do not seek to prohibit private reproduction of the Opera House, but rather to ensure appropriate commercial exploitation. ${ }^{81}$ This approach manifests a balance between rights holders and users, which is also relevant to freedom of panorama.

73 See for example Lionel Bently and Brad Sherman Intellectual Property Law (4th ed, Oxford University Press, Oxford, 2014) at [18.1].

74 Radford (2007), above $\mathrm{n} 9$, at [37].

75 Italy is particularly vigilant in protecting its cultural heritage. See Codice dei beni culturali e del paesaggio (Decreto legislativo, 22 January 2004, n 42, GU 24/02/2004) (translation: Code of Cultural and Landscape Heritage).

76 Section 44 of the Terrorism Act 2000 (UK) has, for example, been used to prevent photographs being taken of sensitive buildings.

77 See Anna Kingsbury "Copyright Law, Designs Law and the Protection of Public Art and Works on Public Display" (2007) 15 Wai L Rev 78 at 90.

78 See IP Australia "Trade Marks" <www.pericles.ipaustralia.gov.au>. For a discussion, see Matthew Rimmer "Crystal Palaces: Copyright Law and Public Architecture" (2002) 14 Bond LR 320.

79 Bernard Lane "Iconic image of Opera House no longer public" The Australian (online ed, Australia, 25 January 2014). Numerous images of the Opera House are registered trademarks, including a photograph registered in 2008: see IP Australia "Trade Marks" <www.pericles.ipaustralia.gov.au>.

80 Copyright Act 1968 (Cth), s 65.

81 Sydney Opera House "Image and Filming FAQ" <www.sydneyoperahouse.com>. 


\section{INTERNATIONAL COMPARISONS}

Since it was revised on 14 July 1967 at Stockholm, the Berne Convention has expressly allowed signatories to adopt national legislation restricting copyright. Although New Zealand was not a signatory of the Stockholm version of the Convention, ${ }^{82}$ the full Berne acquis (body of law) was incorporated into TRIPS. ${ }^{83}$ InfoSoc aims to harmonise implementation of World Intellectual Property Organization (WIPO) treaty obligations, notably the Berne Convention, among European Union members.

\section{A Berne Convention}

The Stockholm Revision of 1967 introduced the first omnibus expression of the authorial right over reproduction to the Berne Convention. ${ }^{84}$ Nevertheless, "it was already there in various forms", 85 and, as Sam Ricketson and Jane Ginsburg observe, "reproduction rights were universally recognized under national legislation". 86 Different jurisdictions had developed a heterogeneous body of exceptions to the principle of exclusive author exploitation, and some of these exceptions had been incorporated into the Convention. ${ }^{87}$ The Swedish-BIRPI Study Group ${ }^{88}$ which was established as a precursor to the Stockholm Conference, identified sculptures or buildings on permanent display in public places as one of the exclusions to copyright enacted by Berne Union members. ${ }^{89}$ The challenge faced at the Stockholm Conference was to accommodate these exceptions in the text of the Convention with the ex post facto expression of authorial exclusivity which was to be stated in art 9(1). This task was achieved through the crafting of art 9(2) which provides:

82 New Zealand is one of the small number of countries bound by the 1928 Rome version of the Berne Convention: see Jörg Reinbothe and Silke von Lewinski The WIPO Treaties on Copyright: A Commentary on the WCT, the WPPT, and the BTAP (2nd ed, Oxford University Press, Oxford, 2015) at [7.9.13] n 429.

83 See World Trade Organization "United States - Section 110(5) of the US Copyright Act: Report of the Panel" (WT/DS/160/R, 15 June 2000) at [6.63]. New Zealand has been a member of the World Trade Organization and thus bound by TRIPS since 1 January 1995: see World Trade Organization "New Zealand and the WTO" <www.wto.org>.

84 Sam Ricketson and Jane C Ginsburg International Copyright and Neighbouring Rights: the Berne Convention and Beyond Volume 1 (2nd ed, Centre for Commercial Law Studies, Queen Mary College, London, 2006) at [11.06].

85 Christophe Geiger, Daniel Gervais and Martin Senftleben "The Three-Step Test Revisited: How to Use the Test's Flexibility in National Copyright Law" (2014) 29 Am U Intl L Rev 581 at 583.

86 Ricketson and Ginsburg, above n 84, at [13.03].

87 See Berne Convention, above n 14, arts 2bis and 10bis.

88 Bureaux Internationaux Réunis pour la Protection de la Propriété Intellectuelle (translation: United International Bureaus for the Protection of Intellectual Property), an organisation superseded by the World Intellectual Property Organization.

89 Ricketson and Ginsburg, above n 84, at [13.03] n 6. 
It shall be a matter for legislation in the countries of the Union to permit the reproduction of such works in certain special cases, provided that such reproduction does not conflict with a normal exploitation of the work and does not unreasonably prejudice the legitimate interests of the author.

Article 9(2) establishes a three-step test, ${ }^{90}$ which according to Christophe Geiger and his coauthors, "served as a counterweight to the formal recognition of a general right of reproduction". 91 Despite art 9(2) being unanimously accepted at the Conference, "there is still considerable uncertainty and even ambiguity over its scope". ${ }^{92}$ Indeed, in Radford, Keane J found the three-step test unhelpful and "too abstract" in "deciding the ambit of section 73 " and observed: ${ }^{93}$

The values on which the test relies it does not define and each involves choices. Moreover, the 1994 Act must be presumed to be definitive as to what those choices are within New Zealand and is, itself, like TRIPS, a regime of some elasticity.

Following Keane J's lead, this article will consider an appropriate balance in New Zealand's particular context, rather than apply the three-step test.

\section{B InfoSoc}

InfoSoc sought to ensure harmonised implementation of WIPO treaties, including the Berne Convention, among European Union members. ${ }^{94}$ Despite InfoSoc's harmonisation purpose, ${ }^{95}$ not all its provisions are mandatory. Exclusive authorial reproduction rights are guaranteed, however. Article 5(3) provides a list of exceptions or limitations, including "(h) use of works, such as works of architecture or sculpture, made to be located permanently in public places".96 Consequently, within the European Union, the contrasting approaches of, for example, France and Germany can be accommodated, along with the variations manifest in other member states. ${ }^{97}$ Thus, in the opinion of

90 For a full analysis of the three-step test, see Ricketson and Ginsburg, above n 84, at [13.10]-[13.27].

91 Geiger, Gervais and Senftleben, above n 85, at 583.

92 Ricketson and Ginsburg, above n 84, at [13.10].

93 Radford (2007), above n 9, at [19].

94 See Richard Arnold and Eleonora Rosati "Are National Courts the Addressees of the InfoSoc Three-step Test?" (2015) 10 JIPLP 741 at 741.

95 In the European Union, harmonisation directives seek to institute minimum standards, not identical laws. See Klaus-Dieter Borchardt The ABC of European Union Law (Publications Office of the European Union, Luxembourg, 2010) at 89-93.

96 InfoSoc Directive, above n 16, art 5(3).

97 For a discussion, see Aura Bertoni and Maria Lillà Montagnani "Public architectural art and its spirits of instability" (2015) 5 QMJIP 247 at 256-257. 
Garnett and others, "[s]ection 62 appears to fall squarely within art 5(3)(h)", ${ }^{98}$ despite its scope being significantly broader than that of many other Union members.

Freedom of panorama has generated considerable debate in Europe,${ }^{99}$ and, at the time of writing, $\operatorname{art} 5(3)(\mathrm{h})$ is the subject of public consultation. ${ }^{100}$ It is understandable, then, that an exclusion which allows commercial operations to exploit images of public sculptures might receive an unfavourable reception from legislators and judges in countries which have a tradition of strong support for authors' rights. Two prominent examples of European governments adopting a restrictive approach to freedom of panorama are provided by a Swedish Supreme Court decision and a recent amendment of the French intellectual property code.

\section{Sweden}

Article 24(1) of the Act on Copyright in Literary and Artistic Works 1960 (Sweden) provides:101

Works of fine art may be reproduced in pictorial form

1. if they are permanently located outdoors on, or at, a public place

Buildings may be freely reproduced in pictorial form.

This provision, which it will be noted is not limited to buildings and sculptures, led to a dispute between Wikimedia and the Swedish Visual Arts Copyright Society (BUS). ${ }^{102}$ BUS claimed that Wikimedia infringed copyright by displaying images of public artworks. The Supreme Court ruled in favour of BUS. ${ }^{103}$ Dimi Dimitrov comments on the decision: ${ }^{104}$

98 Garnett, Davies and Harbottle, above n 50, at [9-171].

99 Julia Reda, a Member of the European Parliament for the German Pirate Party, has been a major contributor to the debate: see Julia Reda (rapporteur) "Implementation of Directive 2001/29/EC on the Harmonisation of Certain Aspects of Copyright and Related Rights in the Information Society" (2015) <www.juliareda.eu>. See also Anne-Catherine Lorrain and Julia Reda "Freedom of Panorama: A Political 'Selfie' in Brussels" (2015) 37 EIPR 753

100 See European Commission "Public Consultation on the Role of Publishers in the Copyright Value Chain and on the 'Panorama Exception'" (23 March 2016) <www.ec.europa.eu>.

101 See World Intellectual Property Organization "Sweden" <www.wipo.int>.

102 For a discussion of the case, see Nedim Malovic "Swedish Supreme Court defines scope of freedom of panorama" (2016) 11 JIPLP 736.

103 Bildupphovsrätt i Sverige (BUS) ek för v Wikimedia Sverige Swedish Supreme Court Ö 849-15, 4 April 2016 available at <www.hogstadomstolen.se>.

104 Dimi Dimitrov "Swedish Supreme Court Rules against Freedom of Panorama" (6 April 2016) EDRi <www.edri.org>. Dimitrov is a representative of Wikimedia (Belgium). 
Their basic conclusion is that the law must be interpreted as conservatively as possible otherwise it would "unreasonably prejudice" the author's financial interests ... To explain the difference between print and online, the ruling states that postcards don't constitute a significant impact on the commercial exploitation, but when it comes to new technologies like the internet, commercial scale can be assumed.

Eleonora Rosati concludes that "the public interest underlying the non-profit and open nature of Wikimedia's database would not offset the prejudice caused to rightholders". 105

\section{France}

In order to promote authors' interests, ${ }^{106}$ France has traditionally shunned freedom of panorama, in particular, commercial exploitation. At the Stockholm Convention, for example, the French delegation proposed copyright exclusions should be restricted to "private and personal use". ${ }^{107}$ In the case of Ashby Donald v France, ${ }^{108}$ which arose from fashion models being photographed in front of well-known buildings, the commercial motive of the photographer was a critical consideration in determining that copyright had been infringed. ${ }^{109}$ The French position has led to seemingly arbitrary outcomes. Many French architectural landmarks, such as the Eiffel Tower, which was built in 1889, are in the public domain and so may be freely copied. However, the tower's lighting was installed in 2003 and is copyright protected. ${ }^{110}$ Consequently, without a freedom of panorama permitted use, the tower could be freely photographed by day and the resultant images commercially exploited, but not at night when it is illuminated. ${ }^{111}$

105 Eleonora Rosati "Swedish Supreme Court Uses Three-step Test to Interpret Restrictively Freedom of Panorama" (6 April 2016) The IPKat <www.ipkitten.blogspot.co.nz>. Dimitrov, above n 104, implausibly argues that the Court took no account of others' interests.

106 See for example Ruth Redmond-Cooper "Moral Rights" in Daniel McClean and Karsten Schubert (eds) Dear Images: Art, Copyright and Culture (Ridinghouse, London, 2002) 69 at 70 on extensive authors' rights under French law.

107 Ricketson and Ginsburg, above n 84, at [13.08].

108 Ashby Donald v France [2013] ECHR 287.

109 Dirk Voorhoof and Inger Høedt-Rasmussen "Copyright vs. freedom of expression" (22 January 2013) ECHR Blog 〈www.echrblog.blogspot.co.nz〉.

110 See World Intellectual Property Organization "IP and Business: Using Photographs of Copyrighted Works and Trademarks" (April 2006) <www.wipo.int>. Under the Copyright Act 1994, such a lighting system might qualify for copyright protection as a sculpture or as a work of artistic craftsmanship, but freedom of panorama should nevertheless apply.

111 See Sharon Daboul "By day and night - two different stories of the Eiffel Tower" (20 February 2015) The Global Legal Post <www.globallegalpost.com>. Conversely and implausibly, Joshua Lobert and others "The EU Public Interest Clinic and Wikimedia present: Extending Freedom of Panorama in Europe" (2015) SSRN <www.poseidon01.ssrn.com> at 4 provide photographing "the Eiffel Tower by night" as an example of freedom of panorama. 
In late 2016, France introduced a limited freedom of panorama. ${ }^{112}$ A natural person may reproduce or represent an architectural work or sculpture that is permanently situated on a public road (voie publique), ${ }^{113}$ provided the act is not done for commercial purposes. The new rule will no doubt remove anomalies, but, as Marie-Andrée Weiss notes, the lack of a definition of commercial use (usage à caractère commercial) is likely to raise new problems. ${ }^{114}$ Would, for example, free blogs, which enjoy some support by advertising, be able to claim the exemption? Despite the remaining problems, the new French law provides an example of balancing the interests of author and user in a way that weighs heavily in favour of the author.

\section{DOES NEW ZEALAND'S FREEDOM OF PANORAMA STRIKE AN APPROPRIATE BALANCE?}

In Radford, Keane J observed: ${ }^{115}$

To the extent that s 73 does speak, it does so plainly. It sets out to allow members of the public, including players in the market, to copy in two-dimensions sculptures permanently in the public domain and even for profit; and it does so by setting aside any copyright in the work that the author might otherwise enjoy.

However s 73 is interpreted, that clear policy is not for compromise.

This conclusion is disputable. Section 73 does not set "aside any copyright in the work", rather it permits certain uses. Furthermore, the purpose of the provision may be clear, although it needed judicial assistance to be effective, but the policy underpinning the exclusion is not evident. No obvious evidence exists that freedom of panorama has ever received appropriate policy consideration in New Zealand or in the United Kingdom, whose legislation New Zealand has followed without serious regard for local circumstances. After the House of Lords debates which preceded the 1911 Act, the freedom of panorama exclusion appears to have been replicated without the benefit of proper consideration. As Garnett and others observe of the current United Kingdom provision, "Parliament

112 Law for a Digital Republic (Loi pour une République numérique), art 39 amends art L.122-5 of the Intellectual Property Code (Code de la propriété intellectuelle 1992), effective from 7 October 2016.

113 The term voie publique can be interpreted narrowly as a public highway (see Edgard Le Docte Legal Dictionary in Four Languages (Sweet \& Maxwell, London, 1982) at 642-643) or more liberally as a mode of public access, including a lane, road or street (see Marie-Hélène Corréard and Valérie Grundy (eds) The Oxford-Hachette French Dictionary (Oxford University Press, Oxford, 2007) at 900). For a discussion on whether a personal photograph taken of Stanley Spencer's 1959 monument to Oscar Wilde in the Père Lachaise cemetery would be exempted under the new law, see Eleonora Rosati "Freedom of panorama in France: could even a visit to Père Lachaise become a problem?" (29 April 2016) The IPKat <www.ipkitten.blogspot.co.nz>.

114 Marie-Andrée Weiss "The new, but narrow, French freedom of panorama exception" (18 October 2016) The 1709 Blog <www.the1709blog.blogspot.co.nz>.

115 Radford (2007), above n 9, at [35]. 
gave the section very little attention during the passage of the Bill."116 No specific explanation was included in the Bills for the 1911, 1962 and 1994 New Zealand Acts; in the Dalglish Report, which, in any event, greatly followed the United Kingdom's Gregory Report ${ }^{117}$ or the reports of the Department of Justice and the Law Commission which preceded the 1994 Act. ${ }^{118}$ A consideration of whether freedom of panorama strikes an appropriate balance between the rights and interests in New Zealand's particular context is then long overdue.

\section{A Artists in General}

Max Patté's Solace in the Wind (2008) is a bronze statue situated on the Wellington dockside near the National Museum of New Zealand Te Papa Tongarewa. This statue has gained iconic status and is much reproduced, typically by tourists in "selfies", but also for commercial purposes. ${ }^{119}$ In a stunt, which echoes Snow v Eaton Centre, ${ }^{120}$ the leading Canadian case on derogatory treatment of an artistic work, "Richard Ban from Projuice produced an image for Whittaker's [a chocolate manufacturer] of some jelly atop the bronze Solace in the Wind statue". ${ }^{121}$ There can be little doubt that this behaviour breaches Patté's moral rights in his sculpture but, after Radford, why would an artist risk their time, money and effort in suing a sizeable business? Freedom of panorama appears to make works such as Solace in the Wind vulnerable to derogatory treatment for commercial gain. ${ }^{122}$ Certainly, no public artwork is likely to remain pristine or will always be treated reverently, ${ }^{123}$ but it

116 Garnett, Davies and Harbottle, above n 50, at [9-170].

117 Report of the Copyright Committee (Cmd 8662, 1951).

118 Law Reform Division, Department of Justice Reform of the Copyright Act 1962 (Discussion Paper, April 1985); and Law Reform Division, Department of Justice The Copyright Act 1962: Options for Reform (1989).

119 For example, valum, the alumnus magazine of the Victoria University of Wellington's Law School, reproduced the sculpture on the cover of its 2015 edition. The magazine respected Patté's moral right to be identified as the author of the work, albeit in a way that was barely readable.

120 Snow v Eaton Centre (1982) 70 CPR (2d) 105 (ONCJ).

121 "Diary" The Dominion Post (Wellington, 28 April 2016) at A17. In 2014, another advertising agency arranged a stunt whereby a fake Whittaker's delivery van crashed into a public sculpture in Paeroa. The sculpture is an oversized bottle of lemon and paeroa which is a marque of the town: see Josh Martin "Pranks reaching global market" (24 December 2014) Stuff <www.stuff.co.nz>.

122 For an argument that "[a] strengthened moral rights framework would also assist in protecting artists' rights while preserving public access", see Kingsbury, above n 77, at 94.

123 Francis Upritchard, one of New Zealand's leading expatriate sculptors, created Loafers (2012), which is displayed on Symonds Street in Auckland. Jeremy Olds records observing "[a] man from a nearby construction site wander between the plinths as he spoke on his iPhone, smoking a cigarette. As he listened, he exhaled deeply, and stubbed out his smoke on the plinth." See Jeremy Olds "Queen of Unease" Sunday Star Times (New Zealand, 22 May 2016) at 19. Similarly, Anthony Gormley's STAY (2015), a sculpture installed in Christchurch's Avon river, "has been dressed in a high-viz vest and even an All Black jersey": see 
is not obvious why these works should be unprotected against commercial exploitation. As the Whitford Committee observed: ${ }^{124}$

Copyright protection finds its justification in fair play. A person works and produces something. The product of his skill and labour ought to belong to him ... only the original author ought to have the right to reproduce the original article and sell the copies thus reproduced. If other people were free to do this they would be making a profit out of the skill and labour of the original author.

This manifestation of fairness must be balanced against fair dealing, but s 73 does not fall within the scope of fair dealing.

Contemporary artists may seek to increase their precarious incomes by selling reproductions of their works in various forms. Dick Frizzell is an artist who has successfully created a market for reproductions of his works on T-shirts and prints, ${ }^{125}$ but must be vigilant against unauthorised reproduction both to protect his revenue but also to prevent shoddy copies diluting his brand. ${ }^{126}$ One of Radford's claims against Hallensteins was that the firm's trivialising of his sculpture through reproduction on T-shirts would impact on his ability to sell small scale casts of TIP to serious collectors. ${ }^{127}$ Ricketson and Ginsburg observe that art 9(2) was intended "to accommodate preexisting exceptions which could confer an economic benefit on someone other than the author". ${ }^{128}$ However, there is no reason why a freedom of panorama exclusion should condone free riding. The more artists seek to commercialise their works in challenging markets, the more their normal right of exploitation is likely to be affected by freedom of panorama.

A public sculpture may bring an artist to the attention of the public and art buyers in ways that a privately exhibited work would not, and so may represent a "loss leader" for an artist who may be compensated through higher prices for future works. A degree of kudos may also accrue to an artist whose sculptures are selected for display in a public place. But similar arguments apply to public murals or paintings displayed in a public gallery. Freedom of panorama seems to treat sculptors unfairly relative to other authors.

Charlie Gates "\$800k Antony Gormley statue acting as a weed catcher" The Press (online ed, Christchurch, 7 June 2016).

124 Whitford Report, above n 43, at 3.

125 See Kim Knight "Pure Greed or Fair Share?" Sunday Star-Times (New Zealand, 15 February 2015) at E38.

126 Tommy Livingston and Marika Hill "Frizzell Vows to Take Legal Action after Finding 'Fakes' on Trade Me" Sunday Star Times (online ed, New Zealand, 15 May 2016).

127 See Radford (2009), above n 9, at [74].

128 Ricketson and Ginsburg, above n 84, at [13.19]. 


\section{B Māori Rights}

Māori sculptures in the public space are typically gifted for particular purposes. They are treasures which Māori, through their carvers, ${ }^{129}$ have chosen to share with others. They are not commodities launched onto the market. Wai-titi Landing (2005) presents an example of such gifting and unintended exploitation. The sculpture consists of two pouwhenua (land-marking posts) carved by Ra Vincent, and is situated near Parliament in Molesworth Street, Wellington. The sculpture is a gift to the city from the Wellington Tenths Trust to "symbolise partnership between the city and local Te Atiawa/Taranaki people". ${ }^{130}$ Several images of the sculpture are available for purchase on Alamy, an online stock photograph collection of Getty images. No identification of Vincent as the author is given and the work itself is, it seems, anonymised and commodified as another's pay-for images of "maori sculptures". ${ }^{131}$ Alamy ensures that its own images cannot be downloaded without payment. ${ }^{132}$

Māori kaitiakitanga (guardianship) of taonga is a consideration specific to New Zealand. Pursuing kaitiakitanga, Wai 262 recommended that kaitiaki (guardians) should be able to control commercial exploitation of taonga. ${ }^{133}$ The report recognised "a wide gap between the protections kaitiaki seek in respect of taonga works and mātauranga [knowledge] Māori, and those that are offered by copyright". ${ }^{134}$ Nevertheless, "[t]he boundaries of IP law are the result of a balancing process based on policy choices and priorities about what to give property rights over and what to allow free use of." ${ }^{135}$ Freedom of panorama could be adjusted to manifest a more appropriate balance between Māori Treaty rights and commercial interests.

\section{Users}

In the age of the selfie, it would often defeat the purpose of taking a photograph if it could not be shared through social media platforms, such as Facebook, Instagram or Snapchat. It seems unlikely, however, that sharing in this way would diminish an author's capacity to commercially exploit their works. Publishing a high-resolution image of an affected work on a not-for-profit website, such as

129 According to Māori tradition, pūmanawa (creative talent) "comes to the individual through the parents and down through one's ancestry ... Whakapapa [genealogy] determines the distributions of talents": see Hirini Moko Mead Tikanga Māori: Living by Māori Values (Huia, Wellington, 2003) at 254-255.

130 See Wellington Sculptures "11. Two pouwhenua, Wai-titi Landing" <www.sculptures.org.nz>.

131 See Alamy <www.alamy.com>. The way the sculpture was identified on the website may result from the words used in the search.

132 Alamy has been accused of wrongly offering copyright images for sale and other sharp practices: see Ben Challis "High noon for Getty Images as a photographer bites back" (2 August 2016) The 1709 Blog <www.the1709blog.blogspot.co.nz>.

133 Wai 262, above n 18, at 702-703.

134 At 39.

135 At 39. 
Wikimedia, may, as the Swedish Supreme Court found, impact on an author's earning capacity. ${ }^{136}$ But that consideration needs to be balanced against the educative value and social utility of reproducing such images. However, it is submitted that non-consensual commercial exploitation is unfair and should not be permitted.

\section{CONCLUSION}

This article has sought to examine freedom of panorama through a specific New Zealand lens and has drawn on overseas arrangements as points of comparison. French law, for example, demonstrates how robust author protections can be compatible with private use. The historical reasons for following United Kingdom legislation in this area are no longer persuasive, if they ever were. The policy underpinning the copyright exclusion may have been clear to the Court in Radford, but it is less obvious why it prevails. Indeed, Keane J accepted, via TRIPS, that art 9(2) requires states "to be sparing in the exceptions to the protection of copyright". ${ }^{137}$

It is time freedom of panorama was given proper consideration in a local context of Treaty obligations, struggling artists and the development of a unique national cultural identity. These considerations are not independent. As Wai 262 noted: ${ }^{138}$

Treaty interests are as often as not in alignment with those of other sectors of the community. To protect

the kaitiaki interest in taonga is in many cases also to protect the taonga for all New Zealanders.

Without questioning the correctness of the decision in Radford, it strains credibility that a large commercial operation should be statutorily empowered to exploit the copyright in a sculpture that happens to be in a public place, but, that if that firm were to copy a mural in public place - perhaps, even, illegal graffiti ${ }^{139}$ - it would constitute copyright infringement. Artists invariably struggle to make a living; allowing commercial operations to exploit works in the public view, without compensating artists, seems out of balance. These are the general concerns that motivated the Swedish Supreme Court and the French legislature to limit freedom of panorama to private, non-commercial use. In the New Zealand context, kaitiaki should be able to object to commercial exploitation of their taonga on permanent public display.

136 See Bildupphovsrätt i Sverige (BUS) ek för v Wikimedia Sverige, above n 103.

137 Radford (2007), above n 9, at [19].

138 Wai 262, above n 18 , at 700 .

139 For arguments that uncommissioned street artists hold copyright in the works, see for example Celia Lerman "Protecting Artistic Vandalism: Graffiti and Copyright Law" (2013) 2 JIPEL 295; and Tomasz Rychlicki "Legal Question about Illegal Art" (2008) 3 JIPLP 393. 
Outside incidental capture or unless the copyright holder agrees, it is submitted that reproduction of artistic works in public view should be restricted to non-commercial use. ${ }^{140}$ This proposal would bring freedom of panorama within the scope of fair dealing. It would also eliminate anomalies between different types of artistic works, and between permanent and temporary exhibitions. Informed by these basic principles, the following policy recommendations are made for s 73 . First, freedom of panorama should apply to all artistic works which are intentionally in public view. (As currently, controllers of galleries and other premises could make no reproduction a condition of entry. ${ }^{141}$ ) Secondly, no distinction should be drawn between temporary and permanent displays. Thirdly, any method of reproduction should be permitted. Fourthly, no reproduction for a commercial purpose should be allowed without the copyright owner's permission. Having defined a "public view work" as "a work intentionally displayed for public view, with the permission of the copyright owner", a redrafted s 73 could provide:

Copyright in a public view work is not infringed by copying the work or communicating to the public a copy of the work: provided that no one may commercially exploit a public view work without the permission of the copyright owner.

140 A compulsory licence with fair compensation could be an alternative to a blanket ban on commercial exploitation. Such an arrangement was contemplated by the Main Committee I at the Stockholm Conference: see Ricketson and Ginsburg, above n 84, at [13.25].

141 See Simon Stokes Art and Copyright (2nd ed, Hart, London, 2012) at 67 n 160. 